\title{
Influence of faith-based organisations on HIV prevention strategies in Africa: a systematic review.
}

\author{
Marylyn A Ochillo ${ }^{1}$, Edwin van Teijlingen ${ }^{2}$, Martin Hind ${ }^{1}$
}

1. Faculty of Health and Social Sciences, Bournemouth University.

2. Centre for Midwifery, Maternal \& Perinatal Health, Faculty of Health \& Social Sciences, Bournemouth University.

\begin{abstract}
Background: The HIV/AIDS epidemic remains of global significance and there is a need to target sub-Saharan Africa since it is the hardest hit region worldwide. Religion and more specifically faith-based organisations can have an effect on socio-cultural factors that increase or decrease the risk of infection; and offer preventative interventions to the wider community.

Objective: To understand the influence of faith-based organisations on HIV prevention in Africa.

Method: The main search engine of a British university 'mysearch' was used as this incorporates all relevant databases. Studies were also retrieved by searches within Google scholar, PubMed and reference lists of included papers were hand searched. The authors assessed the relevance of each article separately against the inclusion criteria. The data extraction form was piloted by the first author and cross-checked by the other authors.

Results: Seven studies met all inclusion criteria and were reviewed. Seven individual themes were identified. However, for the purposes of focus within this paper only two themes were focused on.

Conclusion: Given the accessibility of faith-based organisations (FBOs) and the coverage of religion among the population, FBOs are potentially important players in HIV prevention. Therefore, more resources and support should be given to support their health promotion strategies.
\end{abstract}

Keywords: Faith-based organisations, HIV prevention strategies, systematic review.

DOI: https://dx.doi.org/10.4314/ahs.v17i3.18

Cite as: Ochillo MA, Teijlingen EV, Hind M. Influence of faith-based organisations on HIV prevention strategies in Africa: a systematic review. Afri Health Sci. 2017;17(3): 753-761. bttps:// dx.doi.org/10.4314/abs.v17i3.18

\section{Introduction}

HIV (Human Immunodeficiency Virus) and AIDS (Acquired Immuno-Deficiency Syndrome) have some of the highest prevalence rates in sub-Saharan Africa according to the World Health Organization. ${ }^{1}$ Although the pandemic is slowing, more people are now living with HIV and this is partially explained by the increased survival rates due to improved access to anti-retroviral therapy (ART). The high numbers of people living with HIV/ AIDS (PLWHA) is due to improved access to ART. ${ }^{2}$

\section{Corresponding author: \\ Marylyn A Ochillo, \\ Faculty of Health and Social Sciences, \\ Bournemouth University. \\ Email: marilynochillo@yahoo.com}

Nevertheless, by virtue of ART's success rate, HIV has now become a chronic disease whereby the dominant problem is no longer that of dealing with its acute and life-threatening complications. Rather, clinicians are now confronted with managing a chronic disease that will persist for many decades due to lack of a cure. While there has been significant progress with the provision of life-prolonging and life enhancing combination ART to PLWHA, the number of newly infected individuals with HIV far outstrips the reduction in HIV related morbidity and mortality in Africa. ${ }^{3}$

Religion, and more specifically faith-based organisations (FBOs) such as churches, mosques or synagogues, can (a) have an effect on socio-cultural factors that increase or decrease the risk of infection in society; and (b) offer preventative interventions to their followers or the wider community. FBOs spend a large proportion of their time engaging with the community thereby shaping social

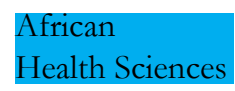

@ 2017 Ochillo et al; licensee African Health Sciences. This is an Open Access article distributed under the termsof the Creative commons Attribution License (https://creativecommons.org/licenses/by/4.0), which permits unrestricted use, distribution, and reproduction in any medium, provided the original work is properly cited. 
norms, attitudes, beliefs and people's reality with regards to sexual self-understanding; making them crucial partners in HIV/AIDS prevention. ${ }^{4}$ FBOs often are a focal point of community life whose influence spreads beyond the traditional role of offering spiritual guidance and comfort.Therefore, in order to successfully address public health issues, FBOs are an obvious partner in preventative activities because of their influence within the African community. ${ }^{5}$ However, the HIV prevention methods of FBOs have been incompatible with the approach of other stakeholders. FBOs often emphasise abstinence and faithfulness as the only strategies for HIV prevention, whereas other stakeholders mainly focus on condom promotion. ${ }^{6}$ The latter approach continues to face opposition from FBOs, since FBOs argue that sexuality cannot be detached from the core values of love, marriage and pro-creation and that by promoting condom use these other stakeholders are encouraging sex outside marriage and promiscuity. ${ }^{7}$
Improved HIV knowledge, the delay of sexual debut and decreased extra- and pre-marital sex is associated with religious commitment. ${ }^{8}$ However, the strong condemnation of condom use potentially reduces knowledge, skills and the willingness of members to use condoms during risky sexual behaviour. ${ }^{8}$ Furthermore, to remain members of good standing within the church, people have to behave in a proscribed manner or face discipline, meaning that the fear of falling out of favour with the church can positively affect their risk-taking behaviours whilst at the same time inhibit the disclosure of such behaviour. ${ }^{8}$ This therefore increases the risk of HIV spread, because PLWHA cannot disclose their sero-status to their partners, or use condoms. ${ }^{6}$

\section{Methods}

A literature search was conducted for English language articles published between 2006 and 2016 using relevant key words (Table 1).

\section{Table 1: Keywords}

\begin{tabular}{|l|l|}
\hline Search term: & Affiliated terms \\
\hline HIV & $\begin{array}{l}\text { hiv or aids or acquired human immunodeficiency syndrome or } \\
\text { human immunodeficiency virus or reproductive health }\end{array}$ \\
\hline $\begin{array}{l}\text { Faith-based } \\
\text { organisation }\end{array}$ & $\begin{array}{l}\text { faith-based organi*ation* or faith based organi*ation* or } \\
\text { religion* or church* or mosque* }\end{array}$ \\
\hline Influence & influence* or impact* or effect* or affect* \\
\hline Strategies & strategy* or initiative* or intervention* \\
\hline Sub-Saharan Africa & $\begin{array}{l}\text { sub-Saharan africa or developing countr* or less developed } \\
\text { countr* or "low-income countr*" }\end{array}$ \\
\hline
\end{tabular}

The Bournemouth University (UK) main search engine 'mysearch' was used as this incorporates all relevant databases (Table 2). Additionally, studies were retrieved by searches within Google scholar, PubMed and the Brit- ish Library. Reference lists of included papers were also checked, and citations in key papers were hand searched'. The search process is presented in a PRISMA flow diagram in figure 1. EndNote software was used to store all the search results. 
Table 2: Databases included through 'mysearch'

\begin{tabular}{|l|l|l|}
\hline Nos. & Name of Database & Hit Count \\
\hline 1 & Social Science Citation Index & 66 \\
\hline 2 & Science Citation Index & 54 \\
\hline 3 & MEDLINE Complete & 35 \\
\hline 4 & PsycINFO & 29 \\
\hline 5 & CINAHL Complete & 15 \\
\hline 6 & SocINDEX with Full Text & 14 \\
\hline 7 & JSTOR Journals & 8 \\
\hline 8 & Arts and Humanities Citation Index & 7 \\
\hline 9 & Science Direct & 7 \\
\hline 10 & Scopus & 5 \\
\hline 11 & Business Source Complete & 3 \\
\hline 12 & Environment Complete & 3 \\
\hline 13 & British Library EthOS & 3 \\
\hline 14 & Education Source & 3 \\
\hline 15 & SCiELO & 2 \\
\hline 16 & ERIC & 1 \\
\hline 17 & Communication Abstract & 1 \\
\hline
\end{tabular}

Table 3: Inclusion and exclusion criteria

\begin{tabular}{|c|c|}
\hline Inclusion criteria & Exclusion criteria \\
\hline $\begin{array}{l}\text { HIV prevention strategies i.e. condom use, } \\
\text { mother-to-child transmission, HIV testing } \\
\text { and counselling, HIV disclosure, stigma } \\
\text { discrimination reduction, sex education, } \\
\text { advertising and campaigns }\end{array}$ & $\begin{array}{l}\text { HIV treatment interventions i.e. ARTs and } \\
\text { ARVs }\end{array}$ \\
\hline $\begin{array}{l}\text { FBO or churches or mosques or temple or } \\
\text { any other place of worship involved in } \\
\text { either of the prevention strategies }\end{array}$ & $\begin{array}{l}\text { HIV prevention strategies that affiliated to } \\
\text { or lead and organized by secular non- } \\
\text { government organisations }\end{array}$ \\
\hline $\begin{array}{l}\text { Participants in the studies were either } \\
\text { affected or infected with HIV and were } \\
\text { affiliated or belonged to a religion }\end{array}$ & $\begin{array}{l}\text { Participants not affected or infected with } \\
\text { HIV and were not affiliated or belonged to } \\
\text { any religion }\end{array}$ \\
\hline $\begin{array}{lrr}\text { Prevention strategies were being } \\
\text { implemented in sub-Sahara Africa }\end{array}$ & $\begin{array}{l}\text { on strategies that were being } \\
\text { ented outside sub-Saharan Africa }\end{array}$ \\
\hline $\begin{array}{l}\text { Studies published in English between } 2006 \\
\text { and } 2016\end{array}$ & $\begin{array}{l}\text { Non-English language studies published } \\
\text { before } 2006 \text { and those lacking publication } \\
\text { date/authors }\end{array}$ \\
\hline
\end{tabular}

Study selection and data extraction

After assessing the relevance of each article separately against the inclusion criteria (Table 3), the authors came up with a list of studies with reasons for inclusion or exclusion. CASP (Critical Appraisal Skills Programme) tools were used to assess the quality of the studies. ${ }^{10}$ Before the critical appraisal of each paper, the CASP tools were piloted using two studies to see if they "work". Two authors independently piloted the CASP tools. After completion of the quality assessment, responses were compared, differences discussed and issues resolved. 
Table 4 summarises the data extracted from the studies. The data extraction form was also piloted on two studies by the first author. To ensure accuracy and completeness of the data extracted, the other authors cross-checked the extracted data and necessary amendments were made af- ter discussions. Thematic analysis generated the themes that answered our research question: What is the influence of FBO's on HIV/AIDS prevention strategies in sub-Sahara Africa? Permission to conduct the systematic review was sought from Bournemouth University Ethical Committee.

Table 4: Summary of selected studies

\begin{tabular}{|c|c|c|c|c|c|c|}
\hline \multicolumn{7}{|c|}{ Details of studies included in the review } \\
\hline Nos. & Reference & Aims and/or objectives & Setting and Population & $\begin{array}{l}\text { Type of HIV } \\
\text { prevention } \\
\text { intervention }\end{array}$ & Authors outcome and Limitations of study & $\begin{array}{l}\text { Reviewers' } \\
\text { conclusion }\end{array}$ \\
\hline 1 & $\begin{array}{l}\text { Eriksson et al. } \\
2014^{11}\end{array}$ & $\begin{array}{l}\text { Describe messages relating to } \\
\text { sexuality and HIV prevention, } \\
\text { given to young people by three } \\
\text { Christian organisations and how } \\
\text { these relate to young people's } \\
\text { lives. }\end{array}$ & $\begin{array}{l}\text { KwaZulu-Natal, South Africa } \\
\text { Young people 15-24 years } \\
\text { attending church conference } \\
\text { and affiliated to e RC } \\
\text { Church, Lutheran Church, or } \\
\text { Assemblies of God. }\end{array}$ & Sex Education & $\begin{array}{l}\text { Most perceived themselves at risk of HIV (53\%), } \\
\text { Premarital sexual abstinence was most frequently }(88 \%) \\
\text { reported prevention message, followed by faithfulness } \\
(23 \%) \text {, HIV testing }(18 \%) \& \text { condom use (17\%). } \\
\text { Limitations: } \\
\text { Open invitation to young people attending church } \\
\text { conference i.e. systematic sample,henceimpossible to } \\
\text { give a response rate. }\end{array}$ & $\begin{array}{l}\text { Study seems valid and reliable. The aim } \\
\text { is clearly highlighted and seems } \\
\text { answerable. Data collection and } \\
\text { analysis methods are discussed in } \\
\text { detail. Findings are also explicit and } \\
\text { discussions are adequate. }\end{array}$ \\
\hline 2 & $\begin{array}{l}\text { Eriksson et al. } \\
2013^{12}\end{array}$ & $\begin{array}{l}\text { Gain deeper understanding of } \\
\text { how young people perceive and } \\
\text { reflect on messages } \\
\text { from churches regarding } \\
\text { premarital sex in context of their } \\
\text { own realities }\end{array}$ & $\begin{array}{l}\text { RC Church, Evangelical } \\
\text { Lutheran Church } \\
\text { and Assemblies of God. } \\
\text { Durban in KwaZulu-Natal, } \\
\text { South Africa } \\
\text { Church-attending youth 13- } \\
20 \text { years }\end{array}$ & $\begin{array}{l}\text { Sex Education } \\
\mathrm{ABCs} \text { (Abstain, } \\
\mathrm{Be} \text { faithful and } \\
\text { Condom use) of } \\
\text { HIV prevention }\end{array}$ & $\begin{array}{l}\text { Church messages were on abstinence thus not addressing } \\
\text { sexually active youths. } \\
\text { Church messages did not address contextual factors such } \\
\text { as peer pressure, drugs \& alcohol i.e. main reasons youth } \\
\text { become sexually active. } \\
\text { Young women were given more information on sexual } \\
\text { issues than men. } \\
\text { HIV testing was only considered just before marriage as } \\
\text { it was used to detect unfaithfulness } \\
\text { Limitations: } \\
\text { Wide age range (13-20 years), attitudes on premarital } \\
\text { sex vary depending on age. }\end{array}$ & $\begin{array}{l}\text { Study seem to be rigorous, researcher } \\
\text { has justified every decision made while } \\
\text { conducting the study. However, } \\
\text { researcher's relationship with } \\
\text { participants is not clearly described. }\end{array}$ \\
\hline 3 & $\begin{array}{l}\text { Trinitapoli } \\
(2009)^{13}\end{array}$ & $\begin{array}{l}\text { 1. Identify overall patterns and } \\
\text { variations in what religious } \\
\text { leaders teach about HIV and } \\
\text { about sexual behaviour. } \\
2 . \quad \text { Assess how religious } \\
\text { organisations impact behaviour of } \\
\text { individuals. }\end{array}$ & $\begin{array}{l}\text { Malawi } \\
\text { Religious leaders }\end{array}$ & $\begin{array}{l}\text { Education } \\
\text { ABCs (Abstain, } \\
\text { Be faithful and } \\
\text { Condom use) of } \\
\text { HIV prevention }\end{array}$ & $\begin{array}{l}\text { Over } 88 \% \text { of religious leaders report preaching about } \\
\text { morality weekly basis;over } 70 \% \text { report addressing sexual } \\
\text { morality, AIDS, and illness weekly. Only } 27 \% \text { of } \\
\text { religious leaders reported ever advising members to use } \\
\text { condoms, and } 95 \% \text { reported privately advising members } \\
\text { on individual basis to cease promiscuous behaviour. } \\
\text { Condom use was low among sexually active } \\
\text { respondents. }\end{array}$ & $\begin{array}{l}\text { Aims are clearly highlighted and seem } \\
\text { to reflect the topic of research. The } \\
\text { selection process of participants is clear } \\
\text { as well as the data analysis process. } \\
\text { Overall, study seems to be rigorous as } \\
\text { all the decisions made during the } \\
\text { research and how they affect study have } \\
\text { been justified hence valid. }\end{array}$ \\
\hline 4 & $\begin{array}{l}\text { Miller, A. N., } \\
\text { and Kyalo, N. } \\
(2013)^{14}\end{array}$ & $\begin{array}{l}\text { 1.Investigate factors affecting } \\
\text { denominational differences in } \\
\text { sexual } \\
\text { attitudes and behaviour of youths, } \\
\text { 2. Investigate specific aspects of } \\
\text { church environment associated } \\
\text { with differences in response of } \\
\text { youths to church messaging about } \\
\text { sexual behaviour. }\end{array}$ & $\begin{array}{l}\text { Church-going } \\
\text { youths 16-21 in Nairobi, } \\
\text { Kenya }\end{array}$ & $\begin{array}{lr}\text { Teachings } & \text { and } \\
\text { messages } & \text { on } \\
\text { sexual behaviour }\end{array}$ & $\begin{array}{l}\text { All explained that their churches taught that sex is good, } \\
\text { but should be saved for marriage. } \\
\text { Condoms were viewed by their churches as promoting } \\
\text { immorality. } \\
\text { Some youths held different views than their churches } \\
\text { about condom use. They agreed that youths should not } \\
\text { have sex before marriage but condoms should be } \\
\text { available as last resort. } \\
\text { Youths identified curiosity, peer pressure, media, and } \\
\text { alcohol as contributing factors to premarital sex not } \\
\text { addressed by church. } \\
\text { Limitations: } \\
\text { Findings are not generalizable. }\end{array}$ & $\begin{array}{l}\text { The problem statements agree with the } \\
\text { title and seem to be of educational } \\
\text { significance and the objectives were } \\
\text { generally answerable. In addition, the } \\
\text { methods used to gather data were } \\
\text { clearly explained and the findings were } \\
\text { well organized and reported } \\
\text { objectively. Overall, every decision } \\
\text { made during the research was justified. }\end{array}$ \\
\hline 5 & $\begin{array}{l}\text { Campbell } \\
\text { al. } 2011^{15}\end{array}$ & $\begin{array}{l}\text { Determine the role churches } \\
\text { currently play in contributing to } \\
\text { HIV/AIDS-related stigma. }\end{array}$ & Systematic review in Africa & Stigma reduction & $\begin{array}{l}\text { HIV prevention messages often limited to } \\
\text { abstinence/fidelity clashing with 'mainstream' HIV } \\
\text { prevention campaigns. } \\
\text { Churreh leaders regarded pro-condom health messages as } \\
\text { sinful, based on their belief that those who adhered to } \\
\text { church teachings would not need condoms. This } \\
\text { implicitly stigmatised anyone wishing to use a condom. } \\
\text { Limitations } \\
\text { Only peer-reviewed literature, important findings } \\
\text { identified by non-academic frontline health and welfare } \\
\text { practitioners which are often published in non-academic } \\
\text { 'grey' literature could have been missed. }\end{array}$ & $\begin{array}{l}\text { The purpose of the study was clearly } \\
\text { and concisely stated and seemed to } \\
\text { agree with the title. The author's } \\
\text { objectives were answerable and the } \\
\text { search strategy clearly explained. } \\
\text { Findings were well organized, } \\
\text { sectioned, and reported objectively and } \\
\text { the limitations of the study highlighted. } \\
\text { Overall the study was rigorously done. }\end{array}$ \\
\hline 6 & $\begin{array}{l}\text { Rankin et al. } \\
2008^{16}\end{array}$ & $\begin{array}{l}\text { Describe perceived power and } \\
\text { influence of religious groups on } \\
\text { risk taking and HIV mitigation } \\
\text { behaviours church members. }\end{array}$ & $\begin{array}{l}\text { Blantyre urban and peri- } \\
\text { urban area and in Lilongwe, } \\
\text { capital of Malawi. } \\
\text { National and central leaders } \\
\text { from } 5 \text { faith-based } \\
\text { organisations }\end{array}$ & $\begin{array}{l}\text { Stigma reduction } \\
\text { Messages on } \\
\text { condom use } \\
\text { ABCs (Abstain, } \\
\text { Be faithful and } \\
\text { Condom use) of } \\
\text { HIV prevention }\end{array}$ & $\begin{array}{l}\text { FBO leaders emphasized abstinence and marital fidelity, } \\
\text { faithfulness as a female virtue, condoms promote sin, } \\
\text { and demonization of government's message on condom } \\
\text { use. }\end{array}$ & $\begin{array}{l}\text { In-depth description of data analysis } \\
\text { process. There is a clear statement of of } \\
\text { how themes were derived from data } \\
\text { thus increasing validity of study. No } \\
\text { justification of the research design. }\end{array}$ \\
\hline 7 & Root (2009) $)^{17}$ & $\begin{array}{l}\text { Explore HIV/ } \\
\text { AIDS-related stigma and role that } \\
\text { religiosity \&church participation } \\
\text { may play in lives of PLHIV. }\end{array}$ & $\begin{array}{l}\text { Swaziland } \\
\text { Church attenders. Most } \\
\text { participants were accessed } \\
\text { through an HIV-support } \\
\text { group and a government } \\
\text { health facility } \\
\text { that provided HTC and low- } \\
\text { cost } \\
\text { ART }\end{array}$ & $\begin{array}{lr}\begin{array}{l}\text { HIV } \\
\text { disclosure } \\
\text { church } \\
\text { settings }\end{array} & \begin{array}{r}\text { self- } \\
\text { in }\end{array} \\
\end{array}$ & $\begin{array}{l}\text { Seven participants }(25 \%) \text { began attending church } \\
\text { services either while they were sick or after HIV } \\
\text { diagnosis and } 46 \% \text { reported making a greater effort to } \\
\text { attend church services post-diagnosis. } \\
11 \text { individuals }(39 \% \text { ) who knew they were } \\
\text { HIV-positive said they had disclosed to their pastors. } \\
\text { Three of these disclosures were made to pastors' wives. } \\
\text { Limitations: } \\
\text { Findings are not generalizable. } \\
\text { Selection bias occurred as purposive sampling was of } \\
\text { individuals who were currently attending church. Thus } \\
\text { those for whom becoming HIV-positive led to a } \\
\text { cessation of church attendance were not accessed. }\end{array}$ & $\begin{array}{l}\text { Aim relevant to study. Researcher has } \\
\text { given reasons as to why chosen } \\
\text { participants were most appropriate. The } \\
\text { selection process is clearly described. } \\
\text { Data collection is clearly discussed and } \\
\text { the method made expliciti. There is an } \\
\text { adequate discussion of the results. } \\
\text { Therefore, study seems reliable and } \\
\text { trustworthy. }\end{array}$ \\
\hline
\end{tabular}




\section{Results}

Seven studies met all inclusion criteria and were reviewed. All conducted between 2006 and 2016. Papers were excluded on the grounds of not covering sub-Sahara Afri- can countries, non-English language or lacking a prevention strategy or intervention that is faith-based. Results of the study selection are shown on the flow diagram in Figure 1.

\section{Figure 1: PRISMA flow diagram}

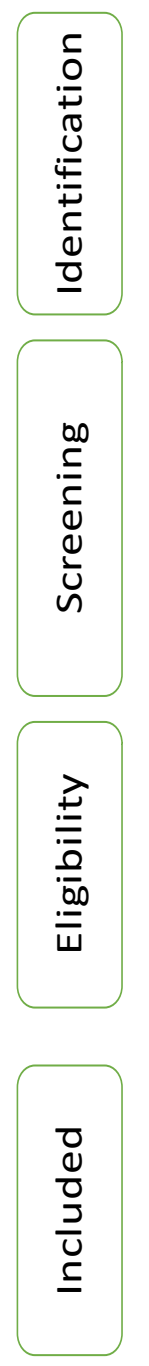

Additional recordsidentified through other sources (Google scholar, PubMed) $(n=13)$

$$
(n=378)
$$

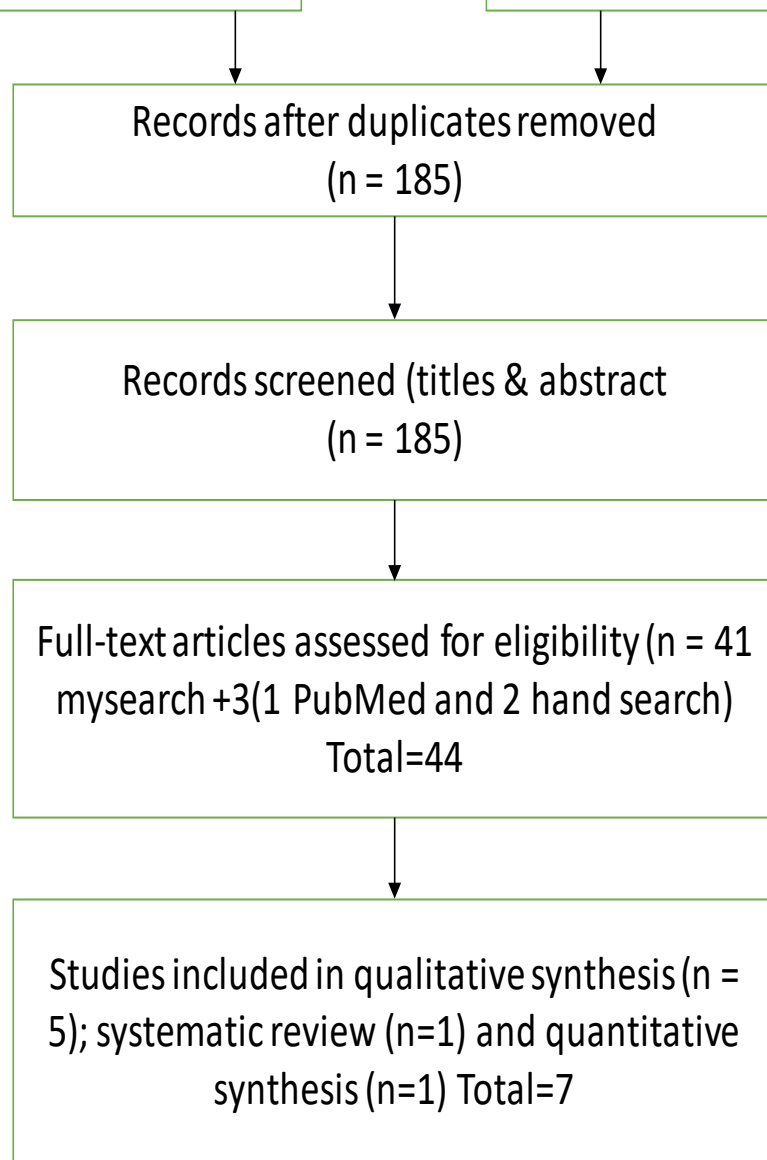

Records excluded

$(n=144)$

Full-text articles excluded, with reasons

$(n=37)$

Key: $\mathrm{n}$ is number of studies included at that level

\section{Description of Included Studies and Participants}

All studies except two were qualitative. Three of the seven studies were conducted in Southern Africa (two in Republic of South Africa and one in Swaziland), two in South-Eastern Africa (Malawi), one in East Africa (Kenya), one was a quantitative study and one a systematic review in Africa. The participants were mainly young peo- ple in faith communities or those affiliated to a church. Religious leaders were also participants in the selected studies. Table 4 summarises the included papers.

Table 5 summarises the key themes from the included papers. However, for the purposes of focus within this paper, the themes 'Wiser decisions regarding sexual behaviour: Condom use' and 'Minimal influence on multiple relationships' were focused on. 
Table 5: Summary of themes in selected studies

\begin{tabular}{|c|c|}
\hline Themes & Studies/references \\
\hline $\begin{array}{l}\text { Wiser decisions regarding sexual } \\
\text { behaviour: Condom use }\end{array}$ & $\begin{array}{l}\text { Eriksson et al. } 2014^{11} \text {; Eriksson et al. } \\
2013^{12} \text {; Trinitapoli } 2009^{13} \text {; Miller \& Ngula } \\
2013^{14} \text {; Campbell et al. } 2011^{15} \text {; Rankin et } \\
\text { al. } 2008^{16}\end{array}$ \\
\hline $\begin{array}{l}\text { Minimal influence on multiple } \\
\text { relationships }\end{array}$ & $\begin{array}{l}\text { Eriksson et al. 2014 } \\
2013^{12} \text {; Eriksson et al. }\end{array}$ \\
\hline $\begin{array}{l}\text { Contextual factors not addressed } \\
\text { during teachings }\end{array}$ & $\begin{array}{l}\text { Eriksson et al. } 2013^{12} \text {; Miller \& Ngula } \\
2013^{14}\end{array}$ \\
\hline Increase in HIV testing & $\begin{array}{l}\text { Eriksson et al. } 2014^{11} \text {; Eriksson et al. } \\
2013^{12} \text {; Root } 2009^{17}\end{array}$ \\
\hline $\begin{array}{l}\text { Abstinence and fidelity: Gender } \\
\text { differences }\end{array}$ & $\begin{array}{l}\text { Eriksson et al. 2014 }{ }^{11} \text {; Eriksson et al. } \\
2013^{12} \text {; Campbell et al. } 2011^{15} \text {; Rankin et } \\
\text { al. } 2008^{16}\end{array}$ \\
\hline Increase in HIV disclosure & Root $2009^{17}$ \\
\hline
\end{tabular}

\section{Wiser decisions regarding sexual behaviour: Con-} dom use.

Wiser decisions on sexual behaviour was identified as an influence of the church teachings on HIV prevention among church-attenders as they paid more attention when making decisions regarding their sexual behaviour. Condom use was the most discussed sexual behaviour and contradicting views were clearly evident. Condom use was controversial as religious leaders held different views. Some religious leaders disapproved of condom use while others cautiously approved condom use to their church members in private.

Religious leaders who disapproved condom use strongly shared the views of many lay Africans, where they dismissed condom use as an impractical HIV prevention strategy that reduces sexual pleasure. ${ }^{13}$ Others had a tendency to equate condom use to promote infidelity and promiscuity thus talked about condoms as promoters of sin during their church teachings. Furthermore, their religious teachings link HIV, condom use and immorality hence suggesting that only non-believers are at risk of HIV infection. This therefore leads to church-going youth perceiving themselves to have little or no risk, lead- ing to inconsistent protective practices.

Religious leaders who are not in complete disapproval of condom use gave advice cautiously to church members. This was seen in religions where they hold a strong negative policy on condom use hence the need to privately advise members of their congregation on condom use. Trinitapoli ${ }^{13}$ argues that young adults who attend religious congregations where their leaders privately advise on condom use are more likely to abstain.

However, young people in faith communities often held different views from their churches on condom use. Although they agreed that youths should not have sex before marriage, they considered the use of condoms as a last resort. It could therefore be suggested that youths engage in less risky behaviour when it comes to HIV prevention. As much as their churches discourage on condom use, they prefered to go against the teachings and practise safer sexual behaviour thus decreasing their risk of HIV infection.

\section{Minimal influence on multiple relationships}

Another theme which emerged from the papers was the influence of the church teachings on multiple relation- 
ships, especially among men. Eriksson and colleagues ${ }^{11,12}$ found that more males than females reported either being in a relationship or having had a relationship. Additionally, both male and female respondents agreed that it was more acceptable for men to have multiple sexual partners as illustrated below:

"...honestly speaking, the truth is, it's hard to abstain" (Boy, AOG: 2). Both young men and women agreed it was more acceptable for men to have multiple sexual partners" (12: -, p 461).

This indicates that gender differences in the number of partners among the religious youth may be similar to those found in youth in the wider society suggesting that affiliation to a religion had a minimal effect on multiple relationships among faith communities.

\section{Discussion}

\section{Wiser decisions regarding sexual behaviour: Con-} dom use

Due to the church teachings and messages on sexual behaviour,church-going youth paid more attention when making sexual behaviour decisions. ${ }^{11}$ Similarly, in a peerled education on sexual behaviour among Malaysian university students aged 18-24 years, participants were found to have sound knowledge and were confident in making wiser decisions regarding sexual behaviour after the intervention. ${ }^{18}$ Therefore, it could be concluded that education interventions on HIV prevention and sexual behaviour among the youth has a strong effect on their sexual behaviour and decisions.

Condom use was the most discussed sexual behaviour and contradicting views was clearly evident. There were those religious leaders who completely disapproved of condom use whereas others cautiously advised members on using condoms. Although young people attending church regularly agreed that sex outside marriage is not acceptable, they still considered condom use as a last resort. Campbell et al. found that youths who self-identified as being religious were less likely to use condoms compared to those who were less attached to a religion. ${ }^{15}$

Therefore, to compare the use of condoms among church-going youths and other youths in general, university students were the comparative group because universities are a priority target area for promoting and enhancing healthy sexual behaviour amongst youths. Additionally, university students are youths who are impressionable, may not have adequate or consistent income, and are living without consistent adult supervision for the first time in their lives. These influencing factors compound with peer pressure make them highly vulnerable to acquiring HIV. Students in the Democratic Republic of Congo aged 18-33 years were less likely to use condoms consistently despite having awareness and access to them. This does not usually translate to the practice of consistent condom use possibly because one of the barriers to condom use amongst students was the influence of their religious advice to not use them. Religion is a major influence in the sexual behaviour of youths. ${ }^{19}$ Furthermore, trust in partners was also a barrier to condom use raising issues of a lack of trust or uncertainty within a relationship making it more difficult for partners to discuss condom use. However, studies in Africa have found that the level of religiosity is a significant predictor of good attitude towards condom use, abstinence and the knowledge towards HIV prevention. ${ }^{20,21,22}$

The low and inconsistent use of condoms amongst the African youth is a crucial factor involved in the large proportion of all new HIV infections occurring in the under 25 year olds. ${ }^{23}$ It is therefore necessary to identify the determinants of risk and protective interventions that are appropriate to this age group. Additionally, the need for combined HIV prevention strategies and interventions that address these specific factors amongst youths, would be the best approach for reducing the prevalence of HIV in the under 25 year olds.

\section{Minimal influence on multiple relationships}

It was clear that despite the religious teachings on HIV and sexual relationships among young people, it was more acceptable for men to have multiple sexual partners than it was for women. This could be because the consequences of pre-marital sex are different for young men and women. ${ }^{11,12}$ Men were regarded as "heroes" among peers for having multiple sexual relationships. In contrast, women who were sexually active were regarded as weak and had a bad reputation. ${ }^{12}$

In Africa, cultural beliefs enforce the view that it is acceptable for a man to have more than one sexual partner. The acceptable norm of men to have multiple relationships is attributed to African societal norms where infidelity is generally accepted for men but not for women. ${ }^{24}$ In addition, the acceptable norm of men to have multiple sexual partners is also attributed to the authority men have over their wives. This authority is established through bride wealth payments and is reinforced by numerous other means, such as the reliance of wives upon their husbands 
for economic and material support. ${ }^{25}$ All studies suggested that it is acceptable for men to have multiple sexual relationships. However, the sexual behaviour among the participants in Bingenheimer's study ${ }^{25}$ was self-reported therefore some reporting bias was likely. Some suggested that affiliation to a religion had minimal influence on multiple relationships among faith communities as gender differences in the number of partners among religious youth is similar to those found in youth in the wider society. ${ }^{11,12,21}$ Therefore, men need more awareness on the risks of having multiple sexual partners given that their behaviour is culturally bound.

\section{Conclusion}

In sub-Saharan Africa, governments often have extremely limited resources to reach all communities in terms of HIV prevention and treatment. Given the accessibility of local FBOs and the coverage of religion among the population, FBOs are potentially important players in HIV prevention and are often in the forefront of responding to the HIV/AIDS epidemic. FBOs can help deliver health promotion messages and materials that are affordable and acceptable. By exploring the influence FBOs have on HIV/AIDS prevention strategies, this research has contributed to a greater understanding of the overall faith-based response to HIV/AIDS in sub-Saharan Africa and how they shape the sexual behaviour of young people. It is hoped that by doing so, FBOs will be better at identifying how best to educate their congregations on HIV prevention thereby improving the overall goal in the fight against HIV/AIDS.

HIV prevention messages are still in line with the already existing traditional messages regarding sexuality. Therefore, FBOs should incorporate amore comprehensive sexual education that addresses the social contexts that makes church-going youth and youth in general vulnerable to HIV infection. The educational messages and teachings seem inappropriate as youths are still sexually active. Hence FBOs need to strengthen their capacity to educate young people in a more holistic way about sexuality and HIV prevention. Furthermore, FBOs should also consider educating and creating awareness on the risks of multiple relationships particularly to those men whose risky behaviour is culturally bound.

More resources should be given to support FBOs in their strategies to prevent HIV infection among faith communities thus improving services. Additionally, governments should offer training to religious leaders on how to pass on their teachings and messages about HIV prevention strategies. This may make them improve their prevention strategies and enhance the understanding of the role FBOs play in HIV/AIDS prevention, care and support. Although our aim was to conduct a review with good quality studies that would be valid and generalizable to sub-Saharan Africa, we acknowledge that this review is limited by the possibility of having missed relevant studies within the timescale and resources available.

\section{Competing interests}

The authors declare no conflict of interest.

\section{References}

1. World Health Organization. 2016. HIV/AIDS. Geneva: WHO, 2016.

2. Deeks SG, Lewin SR, Havlir DV. The end of AIDS: HIV infection as a chronic disease. The Lancet. 2013; 382(9903):1525-33.

3. Vitillo RJ. Faith-based responses to the global HIV pandemic: exceptional engagement in a major public health emergency. Journal of Medicine and the Person. 2009; 7(2):77-84.

4. Muturi N. The interpersonal communication approach to HIV/AIDS prevention strategies and challenges for faith-based organizations. Journal of Creative Communications. 2007 1; 2(3):307-27.

5. Abara W, Coleman JD, Fairchild A, Gaddist B, White J. A faith-based community partnership to address HIV/ AIDS in the Southern United States: Implementation, challenges, and lessons learned. Journal of Religion and Health. 2015; 54(1):122-33.

6. Tiendrebeogo G, Buykx M, van Beelen N. Faith-based responses and opportunities for a multisectoral approach. Sexual Health Exchange. 2004; 1(1):1-3.

7. Farrell M. Condoning or condemning the condom: lessons learned from Uganda. Sexual Health Exchange. 2015 (1):7-8.

8. Lindgren T, Schell E, Rankin S, Phiri J, Fiedler R, Chakanza J. A response to Edzi (AIDS): Malawi faithbased organizations' impact on HIV prevention and care. Journal of the Association of Nurses in AIDS Care. 2013; 24(3):227-41.

9. Armstrong R, Jackson N, Doyle J, Waters E, Howes F. It's in your hands: the value of hand searching in conducting systematic reviews of public health interventions. Journal of Public Health. 2005; 27(4):388-91.

10. Nadelson S, Nadelson LS. Evidence-Based Prac- 
tice Article Reviews Using CASP Tools: A Method for Teaching EBP. Worldviews on Evidence-Based Nursing.2014; 11(5):344-6.

11. Eriksson E, Lindmark G, Haddad B, Axemo P. Young people, sexuality, and HIV prevention within Christian faith communities in South Africa: A cross-sectional survey. Journal of Religion and Health. 2014; 53(6):1662-75.

12. Eriksson E, Lindmark G, Axemo P, Haddad B, Ahlberg BM. Faith, premarital sex and relationships: are church messages in accordance with the perceived realities of the youth? A qualitative study in KwazuluNatal, South Africa. Journal of Religion and Health. 2013; 52(2):454-66.

13. Trinitapoli J. Religious teachings and influences on the ABCs of HIV prevention in Malawi. Social Science \& Medicine. 2009; 69(2):199-209.

14. Miller AN, Ngula KW. The impact of church contextual factors on church-going youth's HIV prevention behaviour in Nairobi, Kenya: A cross-denominational study. African Journal of AIDS Research. 2013; 12(3):131-40.

15. Campbell C, Skovdal M, Gibbs A. Creating social spaces to tackle AIDS-related stigma: reviewing the role of church groups in Sub-Saharan Africa. AIDS and Behavior. 2011; 15(6):1204-19.

16. Rankin SH, Lindgren T, Kools SM, Schell E. The condom divide: disenfranchisement of Malawi women by church and state. Journal of Obstetric, Gynecologic, \& Neonatal Nursing. 2008; 37 (5):596-606.

17. Root R. Religious participation and HIV-disclosure rationales among people living with HIV/AIDS in rural Swaziland. African Journal of AIDS Research. 2009; 8 (3):295-309.
18. Ibrahim N, Rampal L, Jamil Z, Zain AM. Effectiveness of peer-led education on knowledge, attitude and risk behavior practices related to HIV among students at a Malaysian public university - a randomized controlled trial. Preventive Medicine. 2012; 55(5):505-10.

19. Masoda M, Govender I. Knowledge and attitudes about and practices of condom use for reducing HIV infection among Goma University students in the Democratic Republic of Congo. Southern African Journal of Epidemiology and Infection. 2013; 28(1):61-8.

20. Titilayo A, Agunbiade MO, Kehinde O. Perception and Attitudes of Christian Youths towards Condom Use (Implications for HIV/AIDs in Nigeria). African Research Review. 2009;3(1).

21. Manzou R, Schumacher C, Gregson S. Temporal dynamics of religion as a determinant of HIV infection in East Zimbabwe: a serial cross-sectional analysis. PloS one. 2014;9(1): e86060.

22. Kagimu M, Guwatudde D, Rwabukwali C, Kaye S, Walakira Y, Ainomugisha D. Religiosity for HIV prevention in Uganda: a case study among Christian youth in Wakiso district. African health sciences. 2012;12(1):17-25.

23. Mukoma W, Flisher AJ, Ahmed N, Jansen S, Mathews C, Klepp KI, Schaalma H. Process evaluation of a schoolbased HIV/AIDS intervention in South Africa. Scandinavian Journal of Public Health. 2009; 37(2):37-47.

24. Akwara PA, Madise NJ, Hinde A. Perception of risk of HIV/AIDS and sexual behaviour in Kenya. Journal of Biosocial Science. 2003; 35(03):385-411.

25. Bingenheimer JB. Men's Multiple Sexual Partnerships in 15 Sub-Saharan African Countries: Sociodemographic Patterns and Implications. Studies in Family Planning. 2010; 41(1):1-7. 